\title{
The Role of State Attorney Prosecutors to Restore State Financial Losses in Criminal Actions of Corruption to Make Justice
}

\author{
Widya Hari Sutanto*) and Umar Ma'ruf**)
}

*) Student of Master of Law, Faculty of Law, Universistas Islam Sultan Agung Semarang and Attorney of Tegal, E-mail: widyaharisutanto@gmail.com

**) Faculty of Law Universitas Islam Sultan Agung

\begin{abstract}
.
Corruption is very detrimental to state finances or the country's economy and hinders national development, so it must be eradicated in order to create a just and prosperous society based on Pancasila and the 1945 Constitution of the Republic of Indonesia. This study uses a sociological juridical approach, which in this case is related to the role of the State Attorney General in recovering state financial losses with the specification of analytical descriptive research. The data used are primary and secondary data which will be analyzed qualitatively. The research problems were analyzed using the theory of justice and the theory of expediency. The results of the study concluded that the role of the Tegal State Attorney Office in an effort to recover state financial losses can be reviewed in the theory of return on assets and theory of justice which are the most important parts in seeking to recover state financial losses. The return of state financial assets that has been attempted by the Tegal City State Attorney's Office through efforts to confiscate or seize state assets is in accordance with the perspective of justice. Referring to the theory of justice and benefit by placing criminal and civil responsibility on the perpetrators of criminal acts of corruption and their heirs, it is hoped that the state financial losses that occur as a result of these acts can be fully returned as a form of justice for the perpetrators, the state and the community who have been injured. Keywords: Role; State Attorney; Corruption Crime.
\end{abstract}

\section{Introduction}

Forms of irregularities in state finances that result in substantial financial losses to the state are usually the result of criminal acts of corruption committed by irresponsible people. Corruption is very detrimental to state finances or the country's economy and hinders national development, so it must be eradicated in order to create a just and prosperous society based on Pancasila and the 1945 Constitution of the Republic of Indonesia. ${ }^{1}$

State Attorney Prosecutors are prosecutors with special powers, acting for and on behalf of the state or government in civil cases or cases or state administration. ${ }^{2}$ The name State Attorney General (JPN) is not explicitly stated in Act No. 16 of 2004 concerning the Indonesian Prosecutor's Office and the previous Law, namely Act No. 5 of 1991, and Presidential Decree Number 55 of 1991 concerning the Organizational Structure and Work Procedures of the Republican

\footnotetext{
1 Setiawan, Arif dan Umar Ma'ruf. Penerapan Unsur Dapat Merugikan Keuangan Negara Dalam Tindak Pidana Korupsi. Jurnal Hukum Khaira Ummah, Vo.12 No. 3 September 2017.

2 Himpunan petunjuk Jaksa Agung Muda Perdata Dan Tata Usaha Negara (JAM DATUN), XXII, Penerbit:Kejaksaan Agung R.I. p. 2
} 
Attorney General's Office. Indonesia. However, the meaning of "special power" in the civil field itself is synonymous with "lawyer." Based on this assumption, the term state lawyer, which is a translation of the Staatblad 1922 version of Landsadvocaten Number 522 Article 3, is not widely known by the public and the government. ${ }^{3}$

The return of losses from the proceeds of the crime of corruption will prevent the perpetrator from enjoying the results of his actions. This can be done by confiscating certain items obtained or produced in a criminal act of corruption as an additional crime in addition to basic crimes such as imprisonment and fines contained in the Criminal Code Article 10.

In Act No. 31 of 1999 as amended by Act No. 29 of 2001 concerning amendments to Act No. 31 of 1999 concerning Eradication of Corruption, it has been mentioned in Article 18 paragraph (1) which reads:

In addition to additional penalties as referred to in the Criminal Code, additional penalties are:

- Confiscation of movable property that is tangible or intangible or immovable property that is used for or obtained from a criminal act of corruption, including the company owned by the convict where the criminal act of corruption is committed as well as from the goods that replace these items;

- Payment of replacement money in an amount equal to the amount of assets obtained from the criminal act of corruption;

- The closure of all or part of the company for a maximum period of 1 (one) year;

- Revocation of all or part of certain rights or of all or part of certain benefits that have been or can be given by the government to the convicted person.

Corruption as a special crime. One of the duties and powers of the prosecutor's office is to investigate certain crimes based on this law, which is explained in Act No. 16 of 2004 concerning the Republic of Indonesia Prosecutor's Office.

The Tegal City District Attorney's Office in relation to the role of the State Attorney General in recovering state financial losses in the criminal act of corruption certainly did not run smoothly. From the corruption verdict, there is a decision on replacement money, then the special crime field submits its Service Note to the Civil Service and TUN to collect the replacement money that has not been paid by the convict of corruption The amount of the ruling on the replacement money is money that has been enjoyed or corrupted by the convict. If the convict dies, the collection will be addressed to the heirs. If necessary, replacement money will be made to the local PN if the replacement money is still not paid.

Based on the background description above, the author is interested in writing a research entitled "The Role of State Attorneys to Recover State Financial Losses in Corruption Crime to Achieve Justice (Case Study of the Tegal City District Attorney).

The formulation of the problem in this study: What is the role of the state attorney's attorney to recover state financial losses in the criminal act of

\footnotetext{
${ }^{3}$ http://datunkejaritakengon.blogspot.com/p/artikel-hukum.html. Retrieved 17 January 2020.
} 
corruption by the Tegal City District Attorney in order to bring about justice? What are the obstacles and solutions related to the role of the state attorney attorney to recover state financial losses in the criminal act of corruption by the Tegal City District Attorney in order to achieve justice?

The objectives of this study are: To analyze and describe the role of state attorneys and state attorneys to recover state financial losses in corruption crimes by the Tegal City District Attorney to achieve justice; To find out and analyze the obstacles and solutions related to the role of state attorneys and state attorneys to recover state financial losses in criminal acts of corruption by the Tegal City District Attorney to realize justice.

\section{Research methods}

The approach method used in this research uses sociological juridical methods, namely in addition to using legal principles and principles in reviewing, viewing, and analyzing problems, as they are, ${ }^{4}$ which in this case relates to the role of the State Attorney General in recovering state financial losses. The specification in this research is descriptive analytical. Descriptive research is a research method that is intended to describe systematically and accurately the facts and characteristics of the field under study. ${ }^{5}$

Sources of data used in this study are primary, secondary and tertiary data sources.Primary data sources are objects that are observed directly in the field and interviewed informants. ${ }^{6}$ The primary legal materials consist of: Act No. 16 of 2004 concerning the Republic of Indonesia Public Prosecutor's Office. Tertiary legal materials consist of dictionaries, encyclopedias. Data collection methods used to obtain data that have a relationship with the object of research are interviews with sources and document review, while the data analysis method used is qualitative data analysis in this study including data reduction, data presentation and conclusion/verification. ${ }^{7}$

\section{Result and Discussion}

\subsection{The Role of State Attorneys to Recover State Financial Losses in Corruption by the Tegal City District Attorney to Achieve Justice}

The Republic of Indonesia is a constitutional state (rechtsstaat), namely a country in which all attitudes and behavior and actions, whether carried out by the authorities or by its citizens, must be based on law. ${ }^{8}$.Philipus M Hadjon stated that legal protection for the people against government actions is based on two

\footnotetext{
4 Soekanto, Soerjono. (2010). Pengantar Penelitian Hukum. Jakarta: Universitas Indonesia Press. p. 10.

${ }^{5}$ Fajar ND, Mukti and Yulianto Achmad. (2010). Dualisme Penelitian Hukum Normatif dan Empiris. Yogyakarta: Pustaka Pelajat. p. 183.

6 Soerjowinoto, Petrus et al. (2006). Buku Panduan Metode Penulisan Karya Hukum (MPKH) dan Skripsi. Fak.Hukum. Semarang: UNIKA Soegijapranata. p. 15.

${ }^{7}$ Nazir, Moh. (2003). Metodologi Penelitian. Cetakan Ketiga. Jakarta: Ghalia Indonesia. p. 56.

${ }^{8}$ Soehino. (2000). Asas-Asas Hukum Tata Usaha Negara, Jakarta: Liberty. Yogyakarta. p. 195-196.
} 
principles, namely the principle of human rights and the principle of a rule of law. ${ }^{9}$. Conceptually, legal protection for the people of government action includes preventive legal protection and repressive legal protection. In preventive legal protection, the people are given the opportunity to submit objections (inspraak) or their opinions before a government decision takes a definitive form. ${ }^{10}$.

Criminal action is human behavior that is formulated in law, against the law, which deserves to be convicted and committed with wrongdoing. A person who commits a criminal act will be held accountable for the crime if he/she has an error, someone has an error if at the time of committing the act from the perspective of the community it shows a normative view of the wrong done ${ }^{11}$.

The role of the Tegal City State Attorney Attorney in recovering state financial losses in corruption is regulated based on Act No. 16 of 2004 concerning the Indonesian Prosecutor's Office, the provisions of Article 33 and Article 34 of Act No. 20 of 2001 concerning Eradication of Corruption Crimes, related to the existence of a suspect or defendant whose actions are no longer liable to criminal law, because he died during the investigation and/or at the time of examination in court proceedings. This is a legal event that is conditional in nature so that it is impossible for a suspect or defendant to be criminally processed, even though there has been a real loss of state finance.

As for several corruption cases handled, one of them was Decision 77/Pidsus-TPK/2017PN.Smg dated December 6, 2017 which stated that the Defendant was legally and convincingly proven guilty of committing the criminal act of corruption collectively and continued as the primary indictment, and handed down a criminal The defendant will be sentenced to imprisonment for 4 (four) years and a fine of Rp. 200,000,000, - subsidiary 1 (one) month. The next verdict was Decision 26/Pid.Sus-TPK/2020/PN.Smg dated July 1, 2020, which stated that the Defendant had been legally and convincingly proven guilty of committing corruption and sentenced the defendant to 1 (one) year imprisonment. 4 (four) months and stipulate that Rp. 45,516,000 in cash should be returned to those entitled.

The Tegal City State Attorney Attorney in the Corruption Eradication Law has a role, namely to seek the return of state financial losses due to criminal acts of corruption committed by corruptors through civil law instruments. As for the authority is to collect replacement money from the convict/former convict/his heirs based on Article 34c of Act No. 3 of 1971 and seek the return of state financial losses if the criminal process is no longer possible to be carried out under Article 32, Article 33, Article 34, Article 38c of Act No. 31 of 1999 as amended into Act No. 20 of 2001 concerning Eradication of Corruption Crimes.

The Tegal City State Attorney General has the authority to seek to recover state financial losses due to criminal acts of corruption through civil law instruments so that the proceedings are guided by the civil court system. The civil

\footnotetext{
${ }^{9}$ M. Hadjon, Philipus. (2005). Perlindungan Hukum bagi Rakyat di Indonesia. Surabaya: Bina Ilmu. p. 71.

${ }^{10}$ Effendy, Marwan. (2011). Kapita Selekta Hukum Pidana. Jakarta: Referensi. p. 2

${ }^{11}$ Hamzah. Andi. (2001). Bunga Rampai Hukum Pidana dan Acara Pidana. Jakarta: Ghalia Indonesia. p. 22
} 
justice system basically has the same characteristics in almost all over the world, where the initiative to proceed from the parties, the judge is passive and the truth that is sought is formal truth which is tied to legal evidence according to the law.

In the preamble section of the Corruption Crime Law, it has been stated that the criminal act of corruption is very detrimental to state finances or the country's economy and hinders national development, and hinders the growth and continuity of national development which demands high efficiency so that it must be eradicated in order to create a just and prosperous society based on Pancasila. and the 1945 Constitution. Therefore, the law on the eradication of corruption continues to undergo reforms so that it can be applied effectively in the prevention and eradication of corruption. ${ }^{12}$

The ideals of law are formed in the minds and hearts of humans as a product of the integration of world views, religious beliefs and social realities. In line with that, Indonesian law and law should rely on and refer to these ideals of law. ${ }^{13}$ Such a person is a person who is always aware of the problem at hand in its holistic context, so that the attitude or decision taken regarding the issue becomes correct and correct. ${ }^{14}$

\subsection{Constraints and Solutions Related to the Role of State Attorneys}

The Unitary State of the Republic of Indonesia recognizes and upholds human rights and basic human freedoms as rights that are inherently inherent and inseparable from humans that must be protected, respected and upheld in order to enhance human dignity, welfare, happiness, intelligence and justice. 15

Prosecutors as State Attorneys in handling the return of corruption assets, it can be seen that the act of confiscation carried out based on a criminal court decision, there are several obstacles including: ${ }^{16}$

- The perpetrator of the crime made an escape (fugitive). A criminal trial cannot be held if the suspect is a fugitive or is in pursuit.

- The perpetrator of the crime had died or died before being found guilty. Death stops the ongoing criminal justice system process.

- Perpetrators have legal immunity (Immune)

- Perpetrators of crime have the power and power so that the criminal court cannot conduct a trial against him.

- The perpetrator of the crime is not known, but the proceeds of the crime are known/found.

- Criminal assets are controlled by a third party whose legal position is that the third party is innocent and not the perpetrator or not related to the main crime.

\footnotetext{
12 Prasetyo, Rully Trie, Age Ma'ruf, Anis Mashdurohatun. Tindak Pidana Korporasi Dalam Perspektif Kebijakan Formulasi Hukum Pidana. Jurnal Hukum Hukum Khaira Ummah Vol. 12. No. 4 December 2017.

${ }^{13}$ Sidharta, B. Arief. (2010). Ilmu Hukum Indonesia. Bandung: Unika Parahyangan. p. 97

14 Madjid, Nurcholis. (1992). Islam Kemanusiaan dan Kemoderenan, Doktrin dan Peradaban, Sebuah Telaah Kritis tentang Masalah Keimanan. Jakarta: Paramadina Wakaf Foundation.

15 Hamenda, Veive Large. Tinjauan Hak Asasi Manusia Terhadap Penerapan Hukuman Mati Di Indonesia. Jurnal Vol.II/No.1/Jan-Mrt/2013.www.portalgaruda.org.

16 Interview with Jaenudin, SH, MH Tegal City State Attorney Attorney on July 16, 2020
} 
- The absence of sufficient evidence to be presented in a criminal court

- In addition to the aforementioned obstacles, the return of corruption assets by the prosecutor as state attorney is also constrained by the extradition of corruption actors and the return of corrupted assets.

In implementing court decisions regarding additional penalties regarding replacement money through civil instruments, it is often not maximized. This is due to several factors, including: ${ }^{17}$

\subsubsection{Law enforcement factors}

The criminal justice system consists of the investigation sub-system, the prosecutor's sub-system, the court sub-system and the correctional sub-system. In connection with the settlement of the execution of replacement money, it is the authority of the sub-system of the prosecutor's office. The Attorney General's Office in an effort to restore and protect state rights, has the task of settling replacement money through civil suit. However, in practice, the Attorney General has never filed a lawsuit so that the sub-system of the AGO is unable to perform the expected function.

Even though the civil instruments used are outside the criminal justice system, they actually function to settle the replacement money imposed by the criminal court. So that if the sub-system of the Attorney General is dysfunctional, the objectives of the criminal justice system cannot be achieved.

\subsubsection{Facilities and infrastructure/facilities factors that do not support law} enforcement activities

This factor in law enforcement activities can include educated and skilled human resources, good organization, adequate equipment, sufficient finance/budget, and so on. If these things are not fulfilled, it is impossible for the purpose of law enforcement to be achieved.

By placing civil responsibility on the perpetrators of criminal acts of corruption and their heirs, it is hoped that the state financial losses incurred as a result of these acts can be fully returned and at the same time be shock therapy for candidates ?? another potential corruptor because if the corruptor dies before he has had time to pay off and return the corrupted state money, the repayment can still be sued to his heirs.

The problems faced by prosecutors as state lawyers in prosecuting civil liability against perpetrators of criminal acts of corruption and their heirs include 2 (two) factors, including: 18

- The juridical factor for the criminal act of corruption, namely the absence of a power of attorney from the State or agency that has been harmed by the state attorney due to difficulties in proving, the convicted perpetrator of corruption uses legal remedies and clemency, and the investigating prosecutor does not confiscate the assets of the perpetrator of corruption.

\footnotetext{
17 Interview with Yoni P. Artanto, SH, Tegal City State Attorney General on July 19, 2020.

18 Interview with Yoni P. Artanto, SH, Tegal City State Attorney General on July 19, 2020
} 
- Non-juridical factors for criminal acts of corruption, consist of: the convict's assets are insufficient to pay compensation for state losses, the unavailability of the budget for filing a lawsuit and the lack of potential human resources.

Efforts to overcome the constraints on the return of state finances due to corruption, namely: ${ }^{19}$

- It is necessary to make an understanding between law enforcement agencies and state audit institutions (BPKP and BPK) in relation to overcoming obstacles that arise in the implementation of handling corruption cases, especially those relating to the application of elements of state financial losses.

- In the upcoming Corruption Act regulations, the element of state financial loss still needs to be regulated as a formulation of corruption offenses. Not only financial losses to the state but also regional financial losses and the country's economy. ?? state/regional financial losses ?? not only economic (financial) in nature, but also state/regional losses in the form of loss of natural or environmental or ecological resources due to corruption. The state/regional losses referred to are the state/regional losses that have occurred (actual loss) or those that have the potential to occur (potential loss).

- In the event of a? State/regional financial loss? then the agency or agency authorized to carry out the calculation must be expanded not only to the BPK or BPKP or the Accountant Office but also the law enforcement institution as long as the person performing the calculation is a competent person. Institutions or authorized parties in calculating state losses must be affirmed in the new Corruption Act to avoid multiple interpretations and other problems in the future.

\section{Closing}

The results of the study concluded that the role of the Tegal State Attorney Office in an effort to recover state financial losses can be reviewed in the theory of return on assets and theory of justice which are the most important parts in seeking to recover state financial losses. The return of state financial assets that has been attempted by the Tegal City State Attorney's Office through efforts to confiscate or seize state assets is in accordance with the perspective of justice. Referring to the theory of justice and benefit by placing criminal and civil responsibility on the perpetrators of criminal acts of corruption and their heirs, it is hoped that the state financial losses that occur as a result of these acts can be fully returned as a form of justice for the perpetrators, the state and the community who have been injured.

It is necessary to amend the Law on the Prosecutor's Office regarding the regulation and authority of Prosecutors as State Lawyers so that they do not overlap with the Advocate Law. The availability of special funds that are budgeted through the State Revenue and Expenditure Budget is needed to support the return of assets that are spread across several regions and countries and expand cooperation between countries in hunting for corruption assets. The prosecutor

${ }^{19}$ Interview with Agus Wijonarko, SH, Tegal City State Attorney General on July 19, 2020 
not only has the authority as a public prosecutor also has the authority as a State Attorney.

\section{References}

\section{Journals}

[1] Hamenda, Veive Large. Tinjauan Hak Asasi Manusia Terhadap Penerapan Hukuman Mati Di Indonesia. Jurnal Vol.II/No.1/JanMrt/2013.www.portalgaruda.org.

[2] Prasetyo, Rully Trie, Age Ma'ruf, Anis Mashdurohatun. Tindak Pidana Korporasi Dalam Perspektif Kebijakan Formulasi Hukum Pidana. Jurnal Hukum Hukum Khaira Ummah Vol. 12. No. 4 December 2017.

[3] Setiawan, Arif dan Umar Ma'ruf. Penerapan Unsur Dapat Merugikan Keuangan Negara Dalam Tindak Pidana Korupsi. Jurnal Hukum Khaira Ummah, Vo.12 No. 3 September 2017.

\section{Books}

a. Sidharta, B. Arief. (2010). Ilmu Hukum Indonesia. Bandung: Unika Parahyangan.

[2] Effendy, Marwan. (2011). Kapita Selekta Hukum Pidana. Jakarta: Referensi.

[3] Fajar ND, Mukti and Yulianto Achmad. (2010). Dualisme Penelitian Hukum Normatif dan Empiris. Yogyakarta: Pustaka Pelajat.

[4] Hamzah. Andi. (2001). Bunga Rampai Hukum Pidana dan Acara Pidana. Jakarta: Ghalia Indonesia.

[5] Himpunan petunjuk Jaksa Agung Muda Perdata Dan Tata Usaha Negara (JAM DATUN), XXII, Penerbit:Kejaksaan Agung R.I.

[6] M. Hadjon, Philipus. (2005). Perlindungan Hukum bagi Rakyat di Indonesia. Surabaya: Bina Ilmu.

[7] Madjid, Nurcholis. (1992). Islam Kemanusiaan dan Kemoderenan, Doktrin dan Peradaban, Sebuah Telaah Kritis tentang Masalah Keimanan. Jakarta: Paramadina Wakaf Foundation.

[8] Nazir, Moh. (2003). Metodologi Penelitian. Cetakan Ketiga. Jakarta: Ghalia Indonesia.

[9] Soehino. (2000). Asas-Asas Hukum Tata Usaha Negara.Jakarta: Liberty. Yogyakarta.

[10] Soekanto, Soerjono. (2010). Pengantar Penelitian Hukum. Jakarta: Universitas Indonesia Press.

[11] Soerjowinoto, Petrus et al. (2006). Buku Panduan Metode Penulisan Karya Hukum (MPKH) dan Skripsi. Fak.Hukum. Semarang: UNIKA Soegijapranata.

\section{Internet}

[1] http://datunkejaritakengon.blogspot.com/p/artikel-hukum.html. Retrieved 17 January 2020 